\title{
Edukasi Penerapan Protokol Kesehatan Pada Anak Jalanan Akur Kurnia Kramat Jati Jakarta Timur
}

\author{
${ }^{*}$ Suhermi ${ }^{1)}$, Slamet Santoso Kurniawan ${ }^{2)}$, Zulaika $^{3)}$ \\ 1),3)Program Studi DIII ARS, Fakultas Kesehatan, Universitas Mohammad Husni Thamrin \\ ${ }^{2}$ Program Studi DIII Gizi, Fakultas Kesehatan, Universitas Mohammad Husni Thamrin
}

Corresponden author: esuhermi@gmail.com

Received : 4 Desember $2020 \quad$ Accepted : 29 Maret 2021

Published: 30 Maret 2021

DOI: https://doi.org/10.37012/jpkmht.v3i1.450

\begin{abstract}
ABSTRAK
Anak jalanan belum sepenuhnya memahami mengenai pentingnya personal hygiene meskipun ada pemberian beberapa informasi dari volunteer save street child namun pelaksanaan dalam kehidupan sehari-hari belum diterapkan sepenuhnya hal tersebut ditunjukan dengan sikap acuh tak acuh anak jalanan dalam menjaga personal hygiene. Berdasarkan hasil kajian tersebut maka anak jalanan memiliki peluang yang besar terinfeksi virus corona dan media penyebaran virus corona. Metode: kegiatan yang digunakan dalam program pengabdian masyarakat ini berupa penyuluhan edukasi protokol kesehatan dan demontrasi cara mencuci tangan, cara menjaga jarak, cara menggunakan masker dan etika batuk. Hasil: Anak-anak jalanan yang mengikuti penyuluhan dan demontrasi memahami tentang pentingnya penerapan protokol kesehatan selama masa pandemi dan mampu mendemontrasikan ulang. Kesimpulan: kegiatan ini mampu meningkatkan pengetahuan dan pemahaman tentang pentingnya penerapan protokol kesehatan dimasa pandemi covid-19 sehingga dapat diaplikasikan dalam kehidupan sehari-hari.
\end{abstract}

Kata Kunci: Penerapan Protokol Kesehatan.

\begin{abstract}
Introduction: Street children do not fully understand the importance of personal hygiene even though there are several information from volunteers save street children, but the implementation in daily life has not been fully implemented. This is shown by the indifference of street children in maintaining personal hygiene. Based on the results of this study, street children have a great chance of being infected with the corona virus and the media for spreading the corona virus. Methods: activities that have been used in this community service program include educated on health protocols and demonstrations on how to wash hands, how to maintain distance, how to use masks and cough etiquette. Results: Street children who have attended outreach and demonstrations understand the importance of implementing health protocols during the pandemic and are able to demonstrate again. Conclusion: this activity has been carried out to increase knowledge and understanding of the importance of implementing health protocols during the Covid-19 pandemic so that it can be applied in everyday life.
\end{abstract}

Keywords: Implementation Of Health Protocols. 


\section{PENDAHULUAN}

Menurut UNICEF anak jalanan didefinisikan sebagai those who have abandoned their home, school, and immediate communities before they are sixteen yeas of age have drifted into a nomadic street life (anak-anak berumur di bawah 16 tahun yang sudah melepaskan diri dari keluarga, sekolah dan lingkungan masyarakat terdekat, larut dalam kehidupan yang berpindah-pindah). Anak jalanan merupakan anak yang sebagian besar menghabiskan waktunya untuk mencari nafkah atau berkeliaran di jalanan atau tempat-tempat umum lainnya. (Departemen Sosial RI, 2005 dalam Irnawati, Christina, 2018 )

Keterpaksaan hidup dijalanan bukanlah pilihan yang menyenangkan, namun mereka harus menerima karena adanya sebab tertentu. Secara psikologis mereka adalah anak-anak yang pada taraf tertentu belum mempunyai bentukan mental emosional yang kokoh, sementara pada saat yang sama mereka harus bergelut dengan dunia jalanan yang keras dan cenderung berpengaruh bagi perkembangan dan pembentukan kepribadiannya. Aspek psikologis ini berdampak kuat pada aspek sosial. Penampilan anak jalanan yang kumuh, melahirkan pencitraan negatif oleh sebagian besar masyarakat terhadap anak jalanan yang diidentikan dengan pembuat onar, anak-anak kumuh, suka mencuri, dan sampah masyarakat yang harus diasingkan (Armai, 2002).

Lingkungan anak-anak jalanan beraktifitas sangat berpengaruh terhadap pola kesehatan anakanak tersebut, lingkungan yang kurang bersih dapat menyebabkan anak-anak jalanan mudah terpapar infeksi dan penyakit, termasuk virus corona. Nuraini dan Mira Dewi (2009) dalam penelitiannya Pola Aktivitas, Konsumsi Pangan, Status Gizi Dan Kesehatan Anak Jalanan Di Kota Bandung menyatakan bahwa terdapat hubungan yang signifikan antara kebiasaan mencuci tangan menggunakan sabun dengan kejadian diare.

Menghabiskan waktu dijalanan juga menyebabkan anak jalanan rentan terkena virus Corona (Covid-19). Dalam dekade ini Virus Corona telah menggeparkan dunia baik ditingkat global maupun nasional. Virus corona dalam waktu relatif singkat telah menginfeksi 24.551 orang diseluruh dunia dan mengakibatkan 3.827 kematian. Karena virus ini mampu menyebar secara cepat antar manusia dan antar negara termasuk Indonesia (Kemkes, 2020).

Anak jalanan sangat rentan tertular virus ini disebabkan sebagian besar anak jalanan melakukan pekerjaan sebagai pengamen jalanan (93,33 \%) Pramuchtia,Yunda et.al (2010), sehingga mudah terpapar dengan berbagai komunitas orang. Usfaega (2016) dalam penelitian Perilaku Personal Hygiene Terhadap Anak Jalanan di Kota Makassar mnyebutkan bahwa 
anak jalanan belum sepenuhnya memahami mengenai pentingnya personal hygiene meskipun ada pemberian beberapa informasi dari volunteer save street child namun pelaksanaan dalam kehidupan sehari-hari belum diterapkan sepenuhnya hal tersebut ditunjukan dengan sikap acuh tak acuh anak jalanan dalam menjaga personal hygiene. Berdasarkan hasil kajian tersebut maka anak jalanan memiliki peluang yang besar terinfeksi virus corona dan media penyebaran virus corona.

Berbagai aktivitas ekonomi yang dapat dilakukan anak Jalanan "Rumah Singgah Akur Kurnia" di Pasar Induk Kramat Jati misalnya memungut sayuran atau buah-buahan, mengais sampah, memetic cabe, mengupas bawang, memotong bawang, mengupas kelapa, mengojek payung, dan menyemir sepatu. Bila ditinjau dari segi usia anak jalan ini merupakan usia produktif namun mereka tidak menjalankan kehidupan sesuai peran diusianya. Berdasarkan hal tersebut, kami mengusulkan kegiatan Program Pengabdian kepada Masyarakat Kelompok Anak Jalanan di Pasar Kramat Jati Jakarta Timur dengan tujuan untuk mencegah keterpaparan virus corona pada anak-anak jalanan di Rumah Singgah Yayasan Akur Kurnia.

\section{METODE PELAKSANAAN}

Kegiatan pengabdian kepada masyarakat dilaksanakan pada tanggal 8 Oktober 2020 di Rumah Singgah Yayasan Akur Kurnia Kramat Jati Jakarta Timur, sasaran kegiatan anakanak jalanan berusia 5-18 tahun sebanyak 36 orang. Adapun bentuk kegiatan nya adalah (i) memberikan edukasi tentang pencegahan virus corona, (ii) mendemontrasikan cara etika batuk, (iii) mendemontrasikan cara mencuci tangan yang benar, (iv) mendemontrasikan cara menggunakan masker. Penyuluhan dilaksanakan melalui tatap muka atau offline dengan penerapan protokol kesehatan. Alat dan bahan yang digunakan proyektor, LCD, laptop, sabun cuci tangan, masker dan tissue. Kegiatan ini dibagi dalam 4 tahapan yaitu tahap 1 terdiri dari dari perijinan dan persiapan bahan; tahap 2 yaitu pelaksanakan penyuluhan dan demontrasi terbagi dalam 2 kelompok, kelompok 1 di dalam ruangan dan kelompok kedua di dalam ruangan; tahap 3 yaitu praktek demontrasi oleh peserta; tahap ke 4 yaitu pemberikan hadiah kepada peserta yang aktif. Teknik pengabdian kepada masyarakat melaksanakan dengan demontrasi, penyuluhan langsung dan pemutaran video selama 5 menit per materi (mencuci tangan, menjaga jarak, etika batuk, dan memakai masker. 


\section{HASIL DAN PEMBAHASAN}

Pelaksanaan program pengabdian kepada masyarakat di Rumah Singgah Akur Kurnia dilaksanakan pada tanggal 08 Oktober 2020 di Aula Rumah Singgah Akur Kurnia Kramat Jati Jakarta Timur. Kegiatan ini berjalan dengan baik. Sasaran kegiatan ini adalah anak-anak jalanan binaan Yayasan Akur Kurnia Jakarta Timur. Program pengabdian berupa edukasi mengenai penerapan protokol kesehatan era pandemi covid-19 pada anak-anak jalanan dengan metode penyuluhan dan demontrasi langsung.

Materi-materi yang disampaikan ternyata dapat meningkatkan pengetahuan anak-anak jalanan, dengan dibuktikan dengan respon cepat menjawab semua pertanyaan yang diberikan dengan benar serta dapat langsung mempraktekkan bagaimana cara menerapkan protokol kesehatan di era pandemi. Sebagai tolak ukur peningkatan pengetahuan adalah mereka dapat mempraktekkan kembali cara mencuci tangan, etika batuk, menjaga jarak dan menggunakan masker yang benar. Selain itu anak-anak juga dapat mempraktekkan langkah-langkah penerapan protokol kesehatan setelah dipandu oleh mahasiswa dan dibantu dengan media video. Berdasarkan evaluasi selama melaksanakan kegiatan, dapat diidentifikasi faktor pendukung dan penghambat dari kegiatan ini sehingga dapat berjalan dengan baik dan lancar antara lain karena dukungan founder Rumah Singgah Akur Kurnia, pengurus dan pendamping anak-anak jalanan, maka hasil demontrasi dapat dilihat secara rici sebagai berikut:

Hasil demontrasi mencuci tangan sebagai berikut terdapat 4 dari 5 anak yang mendemontasikan mencuci tangan dapat mempraktekkan cara mencuci tangan yang benar. Hasil ini hampir sama dengan pengabmas yang dilaksanakan oleh Irmayani dkk (2020) mengenai Edukasi Tentang Penerapan Protokol Kesehatan Dalam Upaya Pencegahan Covid19 Di Kabupaten Serdang Bedagai Provinsi Sumatera Utara diperoleh hasil 35 responden $(100 \%)$ sudah menerapkan cuci tangan dengan benar. KMK protokol Kesehatan menyatakan bahwa membersihkan tangan secara teratur dengan cuci tangan pakai sabun dengan air mengalir atau menggunakan cairan antiseptik berbasis alkohol/handsanitizer. Selalu menghindari menyentuh mata, hidung, dan mulut dengan tangan yang tidak bersih (yang mungkin terkontaminasi droplet yang mengandung virus). Wirawan (2013) dalam bukunya Kata Dokter, 80 persen dari seluruh kasus penyakit menular ditularkan melalui sentuhan tangan. Jadi, mencuci tangan dengan air mengalir dan sabun adalah cara sederhana yang bisa dilakukan untuk mencegah tertular dan menularkan penyakit. (Irawan Sapto Aji dalam kompas.com).

Pada demontrasi penggunaan masker hasil observasi menunjukkan bahwa 5 dari 5 anak telah 
dapat menggunakan masker dengan benar. Hasil ini hampir sama dengan pengabmas yang dilaksanakan oleh Irmayani dkk (2020) mengenai Edukasi Tentang Penerapan Protokol Kesehatan Dalam Upaya Pencegahan Covid-19 Di Kabupaten Serdang Bedagai Provinsi Sumatera Utara diperoleh hasil 35 responden $(100 \%)$ telah menggunakan masker dengan benar. Dalam KMK Protokol Kesehatan bahwa menggunakan alat pelindung diri berupa masker yang menutupi hidung dan mulut hingga dagu, jika harus keluar rumah atau berinteraksi dengan orang lain yang tidak diketahui status kesehatannya (yang mungkin dapat menularkan COVID-19). Penggunaan masker yang benar dengan menutup hidung dan mulut mampu mencegah anak-anak tertular virus Covid-19. Wiku Adisasmito (2020) mengatakan bahwa Orang yang tidak sadar bahwa dirinya positif corona bisa saja menulari orang lain tanpa sengaja ketika berinteraksi tanpa masker. Satu tetesan (droplet) cairan saja bisa menyebabkan orang lain terkena Covid-19. Untuk mengantisipasi kejadian itu, masyarakat diimbau mengenakan masker ke mana pun pergi di area publik. Namun manfaat masker kain corona tersebut bisa didapatkan selama memenuhi persyaratan untuk mendukung efektivitasnya.

Pada demonterasi sosial distancing atau menjaga jarak, dari hasil observasi diperoleh terdapat 20 anak mampu menerapkan sosial distancing dengan jarak 1 meter, sedangkan 15 anak lainnya masih perlu pendampingan dalam penerapan sosial distancing. Hal ini juga terdapat pada pengabmas yang dilaksanakan oleh Irmayani ddk (2020) bahawa hanya $22 \%$ responden yang menerapkan sosial distancing. Dalam kegiatan ini ada beebrapa faktor yang menyebabkan penerapan sosial distancing kurang berhasil adalah peserta demontrasi adalah anak-anak usia Sekolah Dasar yang masih perlu pendampingan, ruangan tempat penyuluhan yang masih terbatas sehingga harus bergantian dalam melaksanakan penyuluhan dan demontrasi. Menjaga jarak minimal 1 meter dengan orang lain bertjuan untuk menghindari terkena droplet dari orang yang bicara, batuk, atau bersin, serta menghindari kerumunan, keramaian, dan berdesakan (KMK Protokol Kesehatan). Dengan demikian menjaga jarak sangat penting diterapkan karena dapat mencegah anak-anak tertular virus Covid-19 dari orang-orang yang ditemui.

Hasil demontrasi penerapan batuk efektif diperoleh hasil 5 dari 5 anak telah mampu yang memperagakan teknik batuk efektif dengan benar. Mencegah penyebaran suatu penyakit secara luas melalui udara bebas (Droplets) dan membuat kenyamanan pada orang di sekitarnya. Droplets tersebut dapat mengandung kuman infeksius yang berpotensi menular ke orang lain disekitarnya melalui udara pernafasan. Penularan penyakit melalui media udara 
pernafasan disebut air borne disease (FKM, Undip, 2020).

Hasil edukasi adalah anak-anak pengetahuannya meningkat dan paham tentang pentingnya penerapan protokol kesehatan era pandemi dan mampu menerapkan dalam kehidupan seharihari.

\section{SIMPULAN DAN REKOMENDASI}

Pengetahuan meningkat dengan penyuluhan penerapan protokol kesehatan dengan mencuci tangan dengan benar dengan menggunakan penayangan video dan demontrasi oleh mahasiswa. Anak-anak mampu memperagakan penerapan protokol kesehatan, sebagian besar anak-anak jalanan telah mampu melaksanakan penerapan protokol kesehatan dengan baik.

\section{REFERENSI}

1. Kemkes RI (2020), Sehat Corona Jadi Pandemi, Ini Upaya Kemkes-Sehat, dalam sehatnegeriku.kemkes.co.id

2. Kemkes. "Protokol Kesehatan Bagi Masyarakat di Tempat dan Fasilitas Umum Dalam Rangka Pencegahan COVID-19.dalam KMKRI No HK 01.07/Menkes/382/2020

3. Jusfaega et al (2016). Perilaku Personal Hygiene Terhadap Anak Jalanan di Kota Makassar Tahun 2016. Dalam Jurusan Kesehatan Masyarakat UIN Alauddin, Makassar

4. Irnawati, Christina (2018) Hipnoterapi Untuk Peningkatan Perilaku Personal Hygiene Anak Jalanan Di Ppap Seroja Kodya Surakarta. Tesis thesis, Universitas Mercu Buana Yogyakarta

5. Pramuchtia,Yunda et.al. Konsep Diri Anak Jalanan 2010, Kasus Anak Jalanan di kota Bogor.dalam Jurnal Transdisplin Sosiologi, Komunikasi Dan Ekologi Manusia

6. Nur'aini dan Mira Dewi (2009). Pola Aktivitas, Konsumsi Pangan, Status Gizi Dan Kesehatan Anak Jalanan Di Kota Bandung. Jurnal Gizi dan Pangan, Juli 2009 4(2): $97-105$

7. Irmayani, dkk (2020), "Edukasi tentang penerapan protokol kesehatan dalam upaya pencegahan Covid-19 di Kabupaten Serdang Bedagai Propinsi Sumatera Utara.." Dalam Jurnal Pengabdian Kepada Masyarakat Kestra, e-ISSN: Vol. 1 No.1 Edisi Juli 2020 - Januari 2021

8. FKM Undip. “Etika Batuk. " dalam http://fkm.undip.ac.id 